\title{
HOUSEHOLDS' CHARACTERISTICS AND THE MODES OF REMITTANCES IN BANGLADESH
}

\author{
Mehdi Chowdhury* \\ Bournemouth University, Business School, The United Kingdom
}

\begin{abstract}
The modes of remittances of households in Bangladesh have been categorised as 'No Remittances', 'Internal Remittances' and 'International Remittances'. This paper using a Multinomial Logit Model studies the associations between these modes and the households' basic characteristics. The study reveals that household level variables like rural-urban locations, age and sex of the households heads, religion, ratio of male, adult and young members etc. are potentially significant in households' orientation to remittances. Higher education however is not significant. The study surprisingly shows that the households with female heads are more likely to receive both internal and international remittances compared to the households headed by males.
\end{abstract}

JEL Classifications: D01, F24, O53

Keywords: Internal and International Remittances, Households, Bangladesh

Corresponding Author's Email Address: mchowdhury@bournemouth.ac.uk

\section{INTRODUCTION}

Bangladesh is one of the most highly populated countries of the world. It is also one of the leading countries of the world in terms of international labour migration and remittances. However apart from receiving international remittances, many Bangladeshi households receive remittances from family members and other peoples residing in other parts of the country. To be specific, the data of the Household Income and Expenditure Survey (HIES) 2010, conducted by the Bangladesh Bureau of statistics, show that almost $78 \%$ households of Bangladesh received no remittances, about $12 \%$ received internal and about $9 \%$ received international remittances. Internal remittances are therefore, at the outset, no less important than the international remittances for the Bangladeshi households. It is reasonable to assume existence of some associations between a household's characteristics and the mode of remittances of that household. Evaluation of these associations constitutes a starting point of any study and policy debates linking migration, remittances and economic development. No study so far has tried to evaluate these associations in Bangladesh. The paper is aiming to shed some light on these associations using the HIES 2010 data.

The present study is linked to a number of studies that previously investigated the relationships between international migration and remittances in various countries. For example Adams and Cuecuecha (2010) and Adams and Cuecuecha (2013) studied the relationship between remittances, consumption and investment in Guatemala and Ghana using the household income and expenditure survey data of those countries. Mansuri (2006) studied the relationship between migration and educational attainment in rural Pakistan. Acosta et al. (2007) showed that migration positively effected the health and educational expenditures in migrants' households in Latin America. A survey of the literature surrounding the issues is available in Adams (2011).

A number of papers have studied the linkage between migration and remittances in Bangladesh. Mahmud and Osmani (1980) is one of the first studies that investigated the relationship between overseas workers remittances, balance of payment, income and savings of households. Stahl and Habib (1989) using CGE modelling showed that remittances may increase the production of domestic consumption goods as well as the intermediate products necessary to support the increase in consumption. Among the recent studies, Siddique et al. (2012) investigated the causal link between remittances and economic growth in Bangladesh using time series data over a 25-year period which indicated positive effects of remittances on economic growth in Bangladesh. Sikder and Ballis (2013) using an ethnographic study of 36 migrant households across three rural villages in Bangladesh, studied the roles of remittances in shaping the life circumstances of rural migrant households in Bangladesh. Chowdhury and Rabbi (2014) using the annual data from 1971 to 2008 studied the relationship between workers remittances and real exchange rate in 
Bangladesh and showed that influxes of workers' remittances significantly appreciates the real exchange rate and deteriorates the external trade competitiveness. Hatemi-J and Salah Uddin (2014) studied the relationship between poverty reduction and remittances and found that the causality nexus between them is bi-directional.

On the other hand, the present paper contributes by studying the relationship between households characteristics and the mode of remittances in Bangladesh which has not been done by any other study. It also contributes by giving attention to the much neglected issue of internal remittances. The HIES 2010 specifically asked questions about the sources of remittances received by the households. The responses of the households can be categorised in 4 modes of remittances i.e 'No Remittances', 'Internal Remittances', 'International Remittances' and 'Both Internal and International Remittances'. Hence survey responses provide the opportunity to associate the modes of remittances of the households with the households' characteristics using a Multinomial Logit Model (MNL). Adams and Cuecuecha (2010) and Adams and Cuecuecha (2013) used multinomial selection models while estimating the relationship between remittances and consumption. These studies are however specific to Guatemela and Ghana; countries which are in many ways different from Bangladesh. The studies are hence incapable of providing a proper understanding of the activities of the households in Bangladesh.

The study conducted in the present paper delivers some interesting insights on the associations between households' characteristics and the mode of remittances in Bangladesh. A regional disparity in the modes of remittances can be predominantly observed, which shows that some administrative divisions are more likely to receive one type of remittance than the others. Also urban households are less likely to receive internal and international remittances compared to the rural households. The households with female heads are more likely to receive internal and international remittances compared to the households headed by males. Higher education is insignificantly linked with the modes of remittances which may imply that the recent claims of brain gain hypothesis is not applicable in Bangladesh (see Docquir and Rappoport, 2012 for references).

The present study however does not address a number of issues, such as, the network effects of remittances which is currently receiving substantial attentions from the researchers. In addition the reliability of the results of the paper can be improved by addressing a number of econometrics issues, such as endogeneity problem, which we overlook in the paper. We recognise these limitations and therefore propose to consider this paper as an exploratory study in a series of studies linking households and remittances in Bangladesh.

The remainder of the paper is organised as follows. Section 2 discusses the data and provides description and the method of compilation of the variables used. The third section provides descriptive analysis. The regression results are presented in the fourth section. The fifth section concludes the paper. As the descriptive statistics and regression results are cumbersome, they are relegated to the appendix.

\section{DATA DESCRIPTION AND PREPARATION}

The study aims to identify the variables that effect the households' orientation to the modes of remittances in Bangladesh. The data for the analysis came from the Households Income and Expenditure Survey (HIES) of 2010 conducted by Bangladesh Bureau of Statistics (BBS). BBS surveyed total 612 Primary Sampling Units (PSUs) throughout the country (out of 1000 available PSUs). A PSU is defined as contiguous two of more enumeration areas (EA) used in Population and Housing Census 2001. Each PSU comprised of about 200 households out of which 20 households had been surveyed. The survey was completed in one complete year from 1st February, 2010 to 31st January, 2011. In total 12,240 households was surveyed of which 7,840 from rural areas and 4,400 from urban areas.

The data of the survey have been obtained along with the questionnaires from the Bangladesh Bureau of Statistics by the author of the paper. The data is available in STATA files. STATA has also been used for processing the data. Below we describe the procedure of preparing the data ${ }^{1}$ :

Modes of remittances: The information about the mode of remittances is obtained from a question of HIES 2010.

Total income: Obtained from the responses of the households from specific questions. Not used in regression analysis because of the apparent reliability problem.

Total member: The survey gives an identification number to the individuals members of the household. The identification number has been used to count the total members of a household.

\footnotetext{
${ }^{1}$ Please see Table 7: Summary Statistics for list of variables in tabular format.
} 
Rural-Urban Dummy: The survey classifies the locations as rural, urban and Statistical Metropolitan Areas (SMAs). The latter two have been considered by the paper as urban locations.

Ratio of male members: The survey provides information on the sex of the individual members. The information has been used to calculate the number and ratio of total male members of a household.

Sex of households' heads: The survey provides information on the sex and status of individuals members in a household.

Ratio of adult members: Adult members are members aged from 15 to 65.

Ratio of young members: Young members are members aged under 15.

Religion of households' head: The survey provided information on the religions of individual members. The study regards the religion a household the same as the religion of the head.

Any member living abroad: The survey specifically ask question whether any individual member of household lived abroad in the last 5 years. The dummy variable has been complied from that information.

Dummy and ratio for higher education: The survey recorded the educational qualifications of individual members.

Total cultivable land: Directly obtained from the responses of the households from a specific question.

Ratios of food, health and education to total expenditure: The survey recorded the value of itemised expenditure. The ratios have been obtained by aggregating the itemised expenditure data.

All the data as mentioned above have been created from the original data files using mainly the 'Generate', 'Replace' and 'Collapse' commands of STATA. The missing values have been carefully checked for but have not been replaced. The whole process has been conducted with caution. The data files created have been merged together to create the final data file for statistical analysis.

The households have been classified in 4 categories according to the mode of remittances. 9,524 households received 'No Remittances', 1,490 received only 'Internal Remittances', 1,106 households received only 'International Remittances' and 120 households received 'Both Internal and International Remittances'. As 'Both Internal and International Remittances' has only 120 households, this category has been excluded from the subsequent analyses. Hence finally 12,120 households have been used which nonetheless is a substantial number.

\section{DESCRIPTIVE STATISTICS}

This section provides the descriptive statistics of the variables, which will be used in the regression analysis. These descriptive statistics are however extremely informative in revealing the relationship between households' characteristics and the mode of remittances in Bangladesh. Hence, we propose the statistics of this section as one of the stand alone contributions of the study.

The data on the mode of remittances is presented in Table 1 (see Appendix). The table also presents data by the 7 main administrative divisions of Bangladesh. Out of 12,120 households, 9,524 households i.e 78.6 percent did not receive remittances in any form. 12.3 received internal and 9.1 percent received international remittances. Barishal, Khulna, Rajshahi, Rangpur and Syhlet have more than the national average households receiving no remittances. The table also interestingly illuminate on the level of integration of a division with national and international economies. The table shows that Syhlet is less integrated with the national economy as only 6 percent households received internal remittances which is below the national average of 12.2. However Syhlet is more integrated with international economy as 12.6 percent households received international remittances. The table shows that Dhaka and Chittagong are both relatively more integrated with both national and international economies. Rajshahi and Rangpur are lower than national averages in both internal and international remittances hence appear to 
be poorly integrated with the both national and international economies.

Table 2 presents the statistics on the mode of remittances segregating households by rural and urban locations. Total 4,360 households are urban and 7,760 households are rural. The table shows that 81.8 percent of urban households received no remittance compared to 76.8 percent rural households. Rural households are also leading in terms of both internal and international remittances. It indicates both internal and international remittances are relatively prominent in the rural economy compared to the urban economy.

Table 3 presents the statistics on the mode of remittances as per the sex of the households' heads. Out of 12,120 households, only 1,700 i.e. only about 15 percent households have female heads. The table surprisingly reveals that households with female heads are more likely to receive internal and international remittances, as only 45.8 percent the households with female heads received no remittances compared to 83.9 households with male heads. It is also very surprising to see that about 29.6 percent households with female heads received international remittances compared to only about 5.8 percent households with male heads.

Table 4 presents the modes by religion. Islam is the leading religion of Bangladesh. Out of the 12,120 households, i.e. about 88 percent households are Muslim which is at par with the religious demography of Bangladesh. The table shows that Muslim households are more likely to receive internal and international remittances compared to the households of any other religions. The percentages of internal remittances are almost equal (12.6 and 10.3 percent), however the gap between the percentage receiving international remittances is relatively high i.e 9.9 and 3.5 percent.

Table 5 presents the modes of remittances by Education. The 'Yes' column represents the households that have any member with equal or higher than the secondary level of education (equivalent to 0 level in British system). Out of 12,120 households, only 18 percent of households have any member equal or higher than the secondary level of education. The table shows no substantial difference in the modes of remittances by education.

Table 6 links the modes of remittance with international migration. Only 182 households responded to have any member living abroad. As expected, the households with any member living abroad have received more international remittance compared to the households with no one living abroad. However, surprisingly only 30.2 percent of them have reported to have received international remittances which implies rather a weak correlation between international migration and international remittances.

In the next section, we present the regression analysis. The descriptive statistics presented in this section, however have already revealed a few interesting aspects of the households' characteristics and the modes of remittances in Bangladesh. The most striking of them is definitely that a significantly high proportion of households with female heads received both internal and international remittances. These statistics are important for both academicians and policy makers and many would be interested in obtaining further explanation. Such a study would be very useful, but we consider that as beyond the scope of this current paper.

\section{REGRESSION ANALYSIS}

The section presents the results of the regression analysis which associates the modes of remittances with the characteristics of the households. Identification of the relationships between households' properties and the modes of remittances is challenging. The survey has collected substantial information of the households but there can be many unobservable influencing households' orientation to remittances. The results of Multinomial Logit Model (MNL)

below should therefore be interpreted only as associations between the households' characteristics and modes of remittances instead of any causal relationship. As our independent variables does not vary with the choices, we use an alternative invariant model following Cameron and Trivedi (2005) as below:

$$
p_{i j}=\frac{e^{x_{i}^{\prime} \beta_{j}}}{\sum_{l=1}^{3} e^{x_{i}^{\prime} \beta_{l}}}, \quad j=1,2,3
$$

$p_{i j}$ is the probability that household $i$ selects mode $j . x$ is the households' characteristics and $\beta$ implies model parameters. The equation shows the probability of selecting a mode of remittances subject to the characteristics of the household.

Table 7 provides the summary statistics of the variables (Households' characteristics) to be used in the 
regression. Total number of the households in the survey is 12,240. As the households with both internal and international remittances has been excluded, we have in total 12,120 observations on the mode of remittances. However for all other variables except the last three, total observation is 12,240. Each of the last three variables has 12,212 observations which has been caused by the presence of missing values. As the sample size is already fairly large, the missing values should not cause any issues in the regression.

In the micro data analysis, researchers have often suggested avoiding total income because of reliability issues. Table 7 gives indications of why it is so. Many households reported to have no income which causes the median to be equal to zero. We therefore do not use total income in regression.

The table also reports statistics of other variables used. We assume that the locations of the households are important in the modes of remittances. It has been captured by rural urban dummy. Total member of the household varies from 1 to 17. However the mean is 4.5, which is quite standard in Bangladesh households. We assume that the male female ratio in a household may effect the orientation of households to remittances. It is captured by ratio of male members in the households. Similarly we regard that the sex and age of the households' heads will be influential. The mean and median of the age of households heads are in line with the family structures of Bangladesh. However, the minimum and maximum of the households' age are not actually the age at which the a head can effectively lead a family. We therefore run additional regressions for households only with adult heads. The religions of the households and any family member living abroad should effect the households' orientation to remittances. The role of education has been captured by using a dummy for education which is 1 if any member of the households has education higher than higher secondary level. The role of education, additionally, has also been captured by the variable showing the ratio of highly educated members to the total members. Households consumption, health and educational expenditure is also expected to be influential and included in the regression analysis.

Table 8 shows the correlation among the variable used in regression. As expected, relatively high partial correlation can be observed between food, health and educational expenditures. We hence also run regression with only food expenditure to study the sensitivity of the results to the inclusion of health and educational expenditure. We also observe high partial correlation between the ratios of young and adult members of the households. However the results of the regression in table 10 to 23 do not depict any severe consequence of the partial correlation. Researcher have previously noted that the regression with remittances and the expenditure can suffer from simultaneity problem. We cannot ignore the possibility, however the major limitation of the regression analysis is possible existance the household level unobservables. We have overlooked these limitations in the present paper.

The regression results are presented in tables 10 to 23. It is conventional to present regression results in a consolidated form to ease reading and analysing of the results. This consolidation can not be done in the current paper because of the complexity of the results of MNL. Each table hence presents results of only one regression. We however only present the marginal effects, which is the partial derivative of the probabilities with respect to change in the independent variables. For the dummy variables in the model, the marginal effects show the effects of the discrete change of the variables from 0 to 1 . Most of the variables are significant at 1 and 5 percent level. Though the marginal effects show the magnitudes, we are mostly interested in the signs or the directions of the change.

In addition, as the interpretation of the results are long and cumbersome, we only focus on the results of Table 10 where dummy of education instead of ratio has been used. Table 10 also includes all three expenditure variables, i.e. food, health and education. We also run regression classifying the households in three groups according to total expenditure as in table 9. These classifications are to some extent arbitrary. Note that the Bangladesh is a low income developing country where the poverty level expenditure is 60,000 takas yearly. All the regressions, except for the regression with the highest expenditure category, have been clustered by PSUs to control for Heteroskedasticity.

From the results of Table 10, we can observe that the rural location is negatively associated with no remittances and positively, with internal and international remittances. We obtain similar result in table 11 , where ratios instead of education dummy has been used. Similar results can be observed in other tables, except for the households in the highest expenditure category.

Table 10 also shows that the ratio of male members of the household is positively and significantly associated with no remittance, significantly and negatively associated with internal remittance and significantly and positively associated international remittances. The pattern repeats in other regressions with a little exception, in particular, for the highest expenditure category. The result is surprising as it is expected that households with more male members can afford to send more people to work abroad or to other parts of the country.

If the head of the household is female, the probability of receiving no remittances falls and other types of remittances goes up. The pattern repeats in other regressions with only a little exception for the highest expenditure category. One probable explanation is that in Bangladesh the female members become the head of the household mainly after divorce or the death of the husband. The young male members of the household often earn living by working outside of the PSU. The households with female heads are regarded vulnerable hence may receive 
remittances from both close and distant wealthy relatives residing inside or outside of the country. Note however that this explanation is ad-hoc and further research is needed to address this important finding.

Table 10 also shows that age of the households is negatively associated with receiving no remittance, but positively with other modes of remittances. The pattern repeats in other regressions with some exceptions in international remittances. The ratio of adult members of the household is negatively but insignificantly associated with no remittance, significantly and negatively associated with local remittances and significantly and positively associated with international remittances. The pattern repeats in other regressions, but some variations can also be observed. These results should be carefully interpreted because of the correlation of the ratio of adult members with the ratio of young members. In a separate regression (not reported) the ratio of young members was dropped, but no significant variation of the result has been observed. The variable ratio of the young member on the other hand is significantly and negatively associated with no remittance, positively but insignificantly associated with internal and positively and significantly associated with international remittances. The similar patterns are observed in other regressions but there are also some exceptions.

The religion variable is negatively and significantly related to the no remittances, positively but insignificantly related internal and positively and significantly associated with international remittances. The pattern repeats in other regression results. One explanation of this that Bangladesh is a Muslim majority country. Muslim households receive donation from expatriate Bangladeshi Muslims whereas the expatriate non-muslim communities may send less money back home fearing any future religious conflicts. As expected the variable any member living abroad is negatively associated with no remittances and positively with international remittances. It is positively but insignificantly associated with internal remittances, however become significant in the regression only with adult heads. Note that only 182 households reported to have any member living abroad. The number is less than $2 \%$ of the survey sample, which is not representative of a high migration country like Bangladesh.

The higher education variables (both dummy and ratio) surprisingly shows not very significant relationship with the mode of remittances. It is positively but insignificantly associated with no remittances. insignificantly and negatively associated with internal, however, significantly but negatively associated with international remittances. The pattern repeats in other regression which implies that international remittances and higher education are negatively related to each other. This result goes against the recent highly advocated idea of positive relationship between higher education and international migration. The variable total cultivable land proxies the asset positions of the households. Though the variable is insignificant in most of the cases, it is from time to time positively and significantly associated with international remittances. Note also that the coefficients are very small, therefore the influence of the variable is rather negligible.

The next three variables: food, health and education shares are highly correlated with each other. They can well be the source of reverse causality with the mode of remittances. We therefore study the sensitivity of the results under different specifications. No significant variation in results can however be observed. We see that foods share is positively and, health and educational share are negatively associated with no remittances. Food share is negatively, and health and educational share are positively associated with internal and international remittances. One probably explanation is that household with low income is likely to have higher consumption share and less health and educational expenditure. If low income people have weaker networks in the country and abroad, they are less likely to receive money from internal and international sources.

In general it can be observed that though many of the estimated coefficients are statistically significant, the value of the coefficients are often very low. It shows that even if the chosen variables have significant effects they are rather small. The Pseudo R-squares of the regressions are often less that 0.12 which is not unusual in microdata analysis but it shows that there can be significant numbers of unobservables contributing to the households' selection of the modes of remittances. All the results have been tested for the assumption of Independence of Irrelevant Alternative (IAA) using Small and Hsiao test. The results are mixed and do not necessarily reject validity of the assumption in these regressions. We could not conduct likelihood ratio test and Hausmand IIA test as they are not possible in conjunction with the cluster command in STATA.

\section{CONCLUSION AND FURTHER RESEARCH}

The paper used a multinomial logit model to identify the associations of the modes of remittances of the households with the characteristics of the households. The study had some limitations but indicated that modes of remittances selected by the households depends on the households' characteristics like rural urban locations, ratio of male members, sex and age of the heads of the households etc. Higher education was however not an important 
determinant of the households' orientation to remittances. For wealthy households, these characteristics had been only very weakly and insignificantly influential.

We have proposed to regard the study as an exploratory study which will provide direction of future research. For example we found that households with female heads had higher probability of receiving both internal and international remittances. A study can be conducted to identify the reasons and the implications of these remittances to households headed by females. The study also revealed some regional disparities on the households' orientation to remittances. The reason and implications of these also require further deliberation.

It will be also interesting to capture the effects of households' level unobservables, specifically of networks, on the modes of remittances, however HIES did not collect any such information. Future research in this direction would be also very useful. We therefore welcome the researchers and policy makers for suggestions and directions on future research on the causes and effects of different modes of remittances in Bangladesh.

APPENDIX

TABLE 1: MODES OF REMITTANCES BY ADMINISTRATIVE DIVISIONS

\begin{tabular}{|l|c|c|c|c|c|c|c|c|c|c|c|c|c|c|c|c|}
\hline \multirow{2}{*}{ Modes } & \multicolumn{2}{|c|}{ Barisal } & \multicolumn{2}{|c|}{ Chittagong } & \multicolumn{2}{|c|}{ Dhaka } & \multicolumn{2}{|c|}{ Khulna } & \multicolumn{2}{|c|}{ Rajshahi } & \multicolumn{2}{|c|}{ Rangpur } & \multicolumn{2}{|c|}{ Sylhet } & \multicolumn{2}{|c|}{ Total } \\
\cline { 2 - 16 } & No. & $\%$ & No. & $\%$ & No. & $\%$ & No. & $\%$ & No. & $\%$ & No. & $\%$ & No. & $\%$ & No. & $\%$ \\
\hline $\begin{array}{l}\text { No } \\
\text { Remittances }\end{array}$ & 769 & 79.4 & 1,383 & 64 & 2,680 & 76.7 & 1,490 & 83.6 & 1,366 & 86.7 & 1,138 & 89 & 698 & 81.4 & 9,524 & 78.6 \\
\hline $\begin{array}{l}\text { Internal } \\
\text { Remittances }\end{array}$ & 140 & 14.4 & 358 & 16.6 & 474 & 13.6 & 208 & 11.7 & 141 & 8.9 & 118 & 9.2 & 51 & 6 & 1,490 & 12.3 \\
\hline $\begin{array}{l}\text { International } \\
\text { Remittances }\end{array}$ & 60 & 6.2 & 420 & 19.4 & 341 & 9.8 & 85 & 4.8 & 69 & 4.4 & 23 & 1.8 & 108 & 12.6 & 1,106 & 9.1 \\
\hline \begin{tabular}{l} 
Total \\
\hline
\end{tabular} & $\mathbf{9 6 9}$ & $\mathbf{1 0 0}$ & $\mathbf{2 , 1 6 1}$ & $\mathbf{1 0 0}$ & $\mathbf{3 , 4 9 5}$ & $\mathbf{1 0 0}$ & $\mathbf{1 , 7 8 3}$ & $\mathbf{1 0 0}$ & $\mathbf{1 , 5 7 6}$ & $\mathbf{1 0 0}$ & $\mathbf{1 , 2 7 9}$ & $\mathbf{1 0 0}$ & $\mathbf{8 5 7}$ & $\mathbf{1 0 0}$ & $\mathbf{1 2 , 1 2 0}$ & $\mathbf{1 0 0}$ \\
\hline
\end{tabular}

TABLE 2: REMITTANCES BY RURAL URBAN HOUSEHOLDS

\begin{tabular}{|c|c|c|c|c|c|c|}
\hline \multirow[t]{2}{*}{ Modes } & \multicolumn{2}{|c|}{ Urban } & \multicolumn{2}{|c|}{ Rural } & \multicolumn{2}{|c|}{ Total } \\
\hline & No. & $\%$ & No. & $\%$ & No. & $\%$ \\
\hline No Remittances & 3,565 & 81.8 & 5,959 & 76.8 & 9,524 & 78.6 \\
\hline Internal Remittances & 451 & 10.3 & 1,039 & 13.4 & 1,490 & 12.3 \\
\hline \begin{tabular}{|l|} 
International \\
Remittances
\end{tabular} & 344 & 7.9 & 762 & 9.8 & 1,106 & 9.1 \\
\hline Total & 4,360 & 100 & 7,760 & 100 & 12,120 & 100 \\
\hline
\end{tabular}


TABLE 3: REMITTANCES BY SEX OF THE HOUSEHOLDS' HEADS

\begin{tabular}{|c|c|c|c|c|c|c|}
\hline \multirow[t]{2}{*}{ Modes } & \multicolumn{2}{|c|}{ Male } & \multicolumn{2}{|c|}{ Female } & \multicolumn{2}{|c|}{ Total } \\
\hline & No. & $\%$ & No. & $\%$ & No. & $\%$ \\
\hline No Remittances & 8,745 & 83.9 & 779 & 45.8 & 9,524 & 78.6 \\
\hline Internal Remittances & 1,072 & 10.3 & 418 & 24.6 & 1,490 & 12.3 \\
\hline \begin{tabular}{|l|} 
International \\
Remittances \\
\end{tabular} & 603 & 5.8 & 503 & 29.6 & 1,106 & 9.1 \\
\hline Total & 10,420 & 100 & 1,700 & 100 & 12,120 & 100 \\
\hline
\end{tabular}

TABLE 4: REMITTANCES BY RELIGION

\begin{tabular}{|l|l|l|l|l|l|l|}
\hline \multirow{2}{*}{ Modes } & \multicolumn{2}{|c|}{ Islam } & \multicolumn{2}{c|}{ Others } & \multicolumn{2}{c|}{ Total } \\
\cline { 2 - 7 } & No. & \% & No. & No. & No. \\
\hline No Remittances & 8,247 & 77.5 & 1,277 & 86.2 & 9,524 & 1,490 \\
\hline Internal Remittances & 1,337 & 12.6 & 153 & 10.3 & 12.3 \\
\hline $\begin{array}{l}\text { International } \\
\text { Remittances }\end{array}$ & 1,054 & 9.9 & 52 & 3.5 & 9.1 \\
\hline Total & 10,638 & 100 & 1,482 & 100 & 12,120 & \\
\hline
\end{tabular}

TABLE 5: REMITTANCES BY EDUCATION*

\begin{tabular}{|l|c|c|c|c|c|c|}
\hline \multirow{2}{*}{ Modes } & \multicolumn{2}{|c|}{ Yes } & \multicolumn{2}{c|}{ No } & \multicolumn{2}{c|}{ Total } \\
\cline { 2 - 7 } & No. & \% & No. & No. & \% \\
\hline No Remittances & 7,802 & 78.4 & 1,722 & 79.2 & 9,524 & 1,490 \\
\hline Internal Remittances & 1,240 & 12.5 & 250 & 11.5 & 12.3 \\
\hline $\begin{array}{l}\text { International } \\
\text { Remittances }\end{array}$ & 904 & 9.1 & 202 & 9.3 & 9.1 \\
\hline Total & 9,946 & 100 & 2,174 & 100 & 12,120 & \\
\hline
\end{tabular}

*Note: Yes if any member has education equal or higher than secondary level.

TABLE 6: REMITTANCES BY ANY MEMBER LIVING ABROAD

\begin{tabular}{|c|c|c|c|c|c|c|}
\hline \multirow[t]{2}{*}{ Modes } & \multicolumn{2}{|c|}{ Yes } & \multicolumn{2}{|c|}{ No } & \multicolumn{2}{|c|}{ Total } \\
\hline & No. & $\%$ & No. & $\%$ & No. & $\%$ \\
\hline \begin{tabular}{|l|l|} 
No Remittances \\
\end{tabular} & 9,422 & 78.9 & 102 & 56 & 9,524 & 78.6 \\
\hline Internal Remittances & 1,465 & 12.3 & 25 & 13.7 & 1,490 & 12.3 \\
\hline \begin{tabular}{|l|l} 
International \\
Remittances
\end{tabular} & 1,051 & 8.8 & 55 & 30.2 & 1,106 & 9.1 \\
\hline Total & 11,938 & 100 & 182 & 100 & 12,120 & 100 \\
\hline
\end{tabular}


TABLE 7: SUMMARY STATISTICS

\begin{tabular}{|c|c|c|c|c|c|c|}
\hline \begin{tabular}{|l|} 
Variables \\
\end{tabular} & Count & Min & Mean & Median & StDev & Max \\
\hline \begin{tabular}{|l|} 
Modes of \\
Remittances
\end{tabular} & 12,120 & 0 & 0.3 & 0 & 0.6 & 2 \\
\hline \begin{tabular}{|l|} 
Total Income \\
\end{tabular} & 12,240 & 0 & $24,901.60$ & 0 & $95,894.90$ & 5025000 \\
\hline \begin{tabular}{|l|} 
Dummy, \\
rural-urban(Rural=1)
\end{tabular} & 12,240 & 0 & 0.6 & 1 & 0.5 & 1 \\
\hline Total members & 12,240 & 1 & 4.5 & 4 & 1.9 & 17 \\
\hline \begin{tabular}{|l|} 
Ratio of male \\
members
\end{tabular} & 12,240 & 0 & 0.5 & 0.5 & 0.2 & 1 \\
\hline \begin{tabular}{|l} 
Dummy, Sex of \\
heads (Female=1)
\end{tabular} & 12,240 & 0 & 0.1 & 0 & 0.3 & 1 \\
\hline \begin{tabular}{|l|} 
Age of the \\
households' heads \\
\end{tabular} & 12,240 & 11 & 46 & 45 & 13.9 & 122 \\
\hline $\begin{array}{l}\text { Ratio, adult to total } \\
\text { members }\end{array}$ & 12,240 & 0 & 0.6 & 0.6 & 0.2 & 1 \\
\hline $\begin{array}{l}\text { Ratio, young to total } \\
\text { members }\end{array}$ & 12,240 & 0 & 0.3 & 0.3 & 0.2 & 1 \\
\hline \begin{tabular}{|l|} 
Dummy, Religion \\
(Islam=1)
\end{tabular} & 12,240 & 0 & 0.9 & 1 & 0.3 & 1 \\
\hline $\begin{array}{l}\text { Dummy, any } \\
\text { member abroad } \\
(\text { Abroad=1) }\end{array}$ & 12,240 & 0 & 0 & 0 & 0.1 & 1 \\
\hline $\begin{array}{l}\text { Ratio, living abroad } \\
\text { to total members } \\
\end{array}$ & 12,240 & 0 & 0 & 0 & 0 & 1 \\
\hline $\begin{array}{l}\text { Dummy, higher } \\
\text { education (1 if } \geq \\
\text { SSC) }\end{array}$ & 12,240 & 0 & 0.2 & 0 & 0.4 & 1 \\
\hline $\begin{array}{l}\text { Ratio, highly } \\
\text { educated to total } \\
\text { members }\end{array}$ & 12,240 & 0 & 0.1 & 0 & 0.2 & 1 \\
\hline \begin{tabular}{|l|} 
Total cultivable land \\
owned
\end{tabular} & 12,240 & 0 & 55.8 & 0 & 149.1 & $3,960.00$ \\
\hline \begin{tabular}{|l|} 
Share of food to total \\
Consumption
\end{tabular} & 12,212 & 0.1 & 0.7 & 0.7 & 0.1 & 1 \\
\hline \begin{tabular}{|l|} 
Share of health to \\
total expenditure
\end{tabular} & 12,212 & 0 & 0 & 0 & 0 & 0.7 \\
\hline \begin{tabular}{|l|} 
Share of education to \\
total expenditure
\end{tabular} & 12,212 & 0 & 0 & 0 & 0 & 0.6 \\
\hline
\end{tabular}


TABLE 8: CORRELATION MATRIX

\begin{tabular}{|c|c|c|c|c|c|c|c|c|c|c|c|c|c|c|c|c|c|c|}
\hline Variables & Modes & $\begin{array}{l}\text { Total } \\
\text { income }\end{array}$ & $\begin{array}{l}\text { Rural } \\
\text { urban }\end{array}$ & \begin{tabular}{|l} 
Total \\
member \\
s
\end{tabular} & \begin{tabular}{|l|} 
Male \\
members
\end{tabular} & $\begin{array}{l}\text { Sex } \\
\text { head }\end{array}$ & $\begin{array}{l}\text { of Age c } \\
\text { head }\end{array}$ & $\begin{array}{l}\text { of Adult } \\
\text { members }\end{array}$ & \begin{tabular}{|l|} 
Young \\
members
\end{tabular} & $\begin{array}{l}\text { Religio } \\
\text { n }\end{array}$ & $\begin{array}{l}\text { Anybody } \\
\text { abroad }\end{array}$ & $\begin{array}{l}\text { Ratio } \\
\text { abroad }\end{array}$ & \begin{tabular}{|l} 
Ratio \\
educatio \\
n
\end{tabular} & $\begin{array}{l}\text { Anybody } \\
\text { higher } \\
\text { education }\end{array}$ & $\begin{array}{l}\text { Land } \\
\text { owned }\end{array}$ & \begin{tabular}{|l} 
Food \\
expend \\
share
\end{tabular} & $\begin{array}{l}\text { Health } \\
\text { expend } \\
\text { share }\end{array}$ & $\begin{array}{l}\begin{array}{l}\text { Edu } \\
\text { expend } \\
\text { share }\end{array} \\
\end{array}$ \\
\hline Sources & 1 & & & & & & & & & & & & & & & & & \\
\hline Total income & 0.43 & 1 & & & & & & & & & & & & & & & & \\
\hline Rural urban & 0.05 & -0.02 & 1 & & & & & & & & & & & & & & & \\
\hline Total members & -0.01 & 0.05 & 0.03 & 1 & & & & & & & & & & & & & & \\
\hline Male members & -0.15 & -0.07 & -0.03 & 0.12 & 1 & & & & & & & & & & & & & \\
\hline Sex of head & 0.34 & 0.18 & 0.04 & -0.24 & -0.38 & 1 & & & & & & & & & & & & \\
\hline Age of head & 0.09 & 0.07 & 0.04 & 0.12 & 0.01 & 0.01 & 1 & & & & & & & & & & & \\
\hline \begin{tabular}{|l|} 
Adult \\
members
\end{tabular} & -0.06 & -0.01 & -0.1 & -0.22 & 0.11 & -0.05 & 0.09 & 1 & & & & & & & & & & \\
\hline \begin{tabular}{|l} 
Young \\
members
\end{tabular} & 0.01 & -0.01 & 0.06 & 0.33 & -0.02 & -0.01 & -0.41 & -0.77 & 1 & & & & & & & & & \\
\hline \begin{tabular}{|l|} 
Religion \\
\end{tabular} & 0.08 & 0.05 & -0.02 & -0.01 & -0.03 & 0.03 & -0.03 & -0.07 & 0.08 & 1 & & & & & & & & \\
\hline $\begin{array}{l}\text { Anybody } \\
\text { abroad }\end{array}$ & 0.09 & 0.07 & -0.01 & 0.06 & 0.01 & -0.01 & 0.02 & 0.02 & -0.01 & 0.02 & 1 & & & & & & & \\
\hline Ratio abroad & 0.08 & 0.09 & 0 & 0.02 & 0.01 & 0 & 0.01 & 0.02 & -0.02 & 0.02 & 0.89 & 1 & & & & & & \\
\hline \begin{tabular}{|l|} 
Ratio \\
education
\end{tabular} & -0.02 & 0.07 & -0.25 & -0.02 & 0.03 & -0.04 & 0.08 & 0.22 & -0.2 & -0.05 & 0.02 & 0.02 & 1 & & & & & \\
\hline $\begin{array}{l}\text { Anybody } \\
\text { higher } \\
\text { education }\end{array}$ & 0 & 0.08 & -0.22 & 0.1 & 0.04 & -0.05 & 0.11 & 0.19 & -0.17 & -0.03 & 0.02 & 0.02 & 0.85 & 1 & & & & \\
\hline Land owned & 0.05 & 0.13 & 0.08 & 0.12 & 0.02 & -0.04 & 0.15 & 0.05 & \begin{tabular}{|c|}
-0.09 \\
\end{tabular} & -0.02 & 0.03 & 0.02 & 0.18 & 0.21 & 1 & & & \\
\hline $\begin{array}{l}\begin{array}{l}\text { Food expend } \\
\text { share }\end{array} \\
\end{array}$ & -0.12 & -0.19 & 0.23 & 0.08 & 0.03 & -0.06 & -0.03 & -0.17 & 0.16 & 0.02 & -0.04 & -0.04 & -0.4 & -0.38 & -0.15 & 1 & & \\
\hline $\begin{array}{l}\text { Health expend } \\
\text { share }\end{array}$ & 0.07 & 0.08 & 0.04 & -0.01 & -0.02 & 0.01 & 0.06 & 0 & -0.05 & 0 & 0.02 & 0.01 & 0 & 0.01 & 0.06 & -0.26 & 1 & \\
\hline $\begin{array}{l}\text { Edu expend } \\
\text { share }\end{array}$ & 0.04 & 0.07 & -0.16 & 0.12 & 0.03 & 0.01 & 0.04 & 0.06 & 0 & -0.02 & 0 & -0.01 & 0.33 & 0.37 & 0.11 & -0.39 & -0.02 & 1 \\
\hline
\end{tabular}


TABLE 9: REMITTANCES BY EXPENDITURE CATEGORIES (\$1=TK 78.00)

\begin{tabular}{|l|c|c|c|c|}
\hline Modes & $\begin{array}{c}\text { Less than or equal to } \\
\text { Tk 2,00,000 }\end{array}$ & $\begin{array}{c}\text { Tk 2,00,000 to } \\
\text { Tk 5,00,000 }\end{array}$ & $\begin{array}{c}\text { Above } \\
\text { Tk 5,00,000 }\end{array}$ & Total \\
\hline No Remittances & 5,469 & 3,596 & 459 & 9,524 \\
\hline Internal Remittances & 832 & 590 & 68 & 1,490 \\
\hline International Remittances & 371 & 614 & 121 & 1,106 \\
\hline
\end{tabular}


TABLE 10: REGRESSION WITH ALL EXPENDITURE VARIABLES, DUMMY OF EDUCATION

\begin{tabular}{|c|c|c|c|}
\hline VARIABLES & No Remittances & Internal Remittances & International Remittances \\
\hline Dummy (Rural=1) & $\begin{array}{r}-0.0477 * * * \\
(0.0148)\end{array}$ & $\begin{array}{r}0.0293 * * \\
(0.0124)\end{array}$ & $\begin{array}{r}0.0184 * * \\
(0.00715)\end{array}$ \\
\hline Ratio of male & $\begin{array}{r}0.0197 * * * \\
(0.00484)\end{array}$ & $\begin{array}{r}-0.0110^{* * * *} \\
(0.00421)\end{array}$ & $\begin{array}{r}-0.00870 * * * \\
(0.00249)\end{array}$ \\
\hline Dummy(Female head=1) & $\begin{array}{r}-0.361 * * * \\
(0.0173)\end{array}$ & $\begin{array}{r}0.110^{* * * *} \\
(0.0131)\end{array}$ & $\begin{array}{r}0.251 * * * \\
(0.0162)\end{array}$ \\
\hline Age of Head & $\begin{array}{r}-0.00332 * * * \\
(0.000300)\end{array}$ & $\begin{array}{r}0.00222^{* * *} \\
(0.000233)\end{array}$ & $\begin{array}{r}0.00110^{* * * *} \\
(0.000186)\end{array}$ \\
\hline Ratio of Adults & $\begin{array}{r}-0.00299 \\
(0.00395)\end{array}$ & $\begin{array}{r}-0.00912 * * * \\
(0.00325)\end{array}$ & $\begin{array}{r}0.0121 * * * \\
(0.00226)\end{array}$ \\
\hline Ratio of Young & $\begin{array}{r}-0.0209 * * * \\
(0.00391)\end{array}$ & $\begin{array}{r}0.00355 \\
(0.00347)\end{array}$ & $\begin{array}{r}0.0174^{* * * *} \\
(0.00212)\end{array}$ \\
\hline Dummy (Islam=1) & $\begin{array}{r}-0.0717^{* * * *} \\
(0.0145)\end{array}$ & $\begin{array}{c}0.0246 * \\
(0.0132)\end{array}$ & $\begin{array}{r}0.0471^{* * * *} \\
(0.00586)\end{array}$ \\
\hline Dummy (Abroad=1) & $\begin{array}{r}-0.209 * * * \\
(0.0419)\end{array}$ & $\begin{array}{r}0.0419 \\
(0.0289)\end{array}$ & $\begin{array}{r}0.167 * * * \\
(0.0334)\end{array}$ \\
\hline Dummy (1 if $\geq$ SSC) & $\begin{array}{r}0.0200 * \\
(0.0120)\end{array}$ & $\begin{array}{r}-0.00510 \\
(0.00977)\end{array}$ & $\begin{array}{r}-0.0149 * * \\
(0.00615)\end{array}$ \\
\hline Cultivable land & $\begin{array}{r}-0.0000412 \\
(0.000027)\end{array}$ & $\begin{array}{r}0.00000918 \\
(0.0000223)\end{array}$ & $\begin{array}{r}0.000032 * * * \\
(0.0000109)\end{array}$ \\
\hline Food share in expenditure & $\begin{array}{r}0.279 * * * \\
(0.0409)\end{array}$ & $\begin{array}{r}-0.101 * * * \\
(0.0353)\end{array}$ & $\begin{array}{r}-0.179 * * * \\
(0.0201)\end{array}$ \\
\hline Health share in expenditure & $\begin{array}{r}-0.450 * * * \\
(0.115)\end{array}$ & $\begin{array}{r}0.393 * * * \\
(0.0879)\end{array}$ & $\begin{array}{r}0.0570 \\
(0.0603)\end{array}$ \\
\hline Education share in expenditure & $\begin{array}{r}-0.115 \\
(0.0931)\end{array}$ & $\begin{array}{r}0.0558 \\
(0.0765)\end{array}$ & $\begin{array}{r}0.0596 \\
(0.0447)\end{array}$ \\
\hline Observations & 12,092 & 12,092 & 12,092 \\
\hline
\end{tabular}

*Note: Standard errors in parentheses. *** $p<0.01$, ** $p<0.05$, * $p<0.1$. Pseudo $R^{2}=0.1147$ 
TABLE 11: ALL EXPENDITURES VARIABLES, RATIO OF EDUCATION

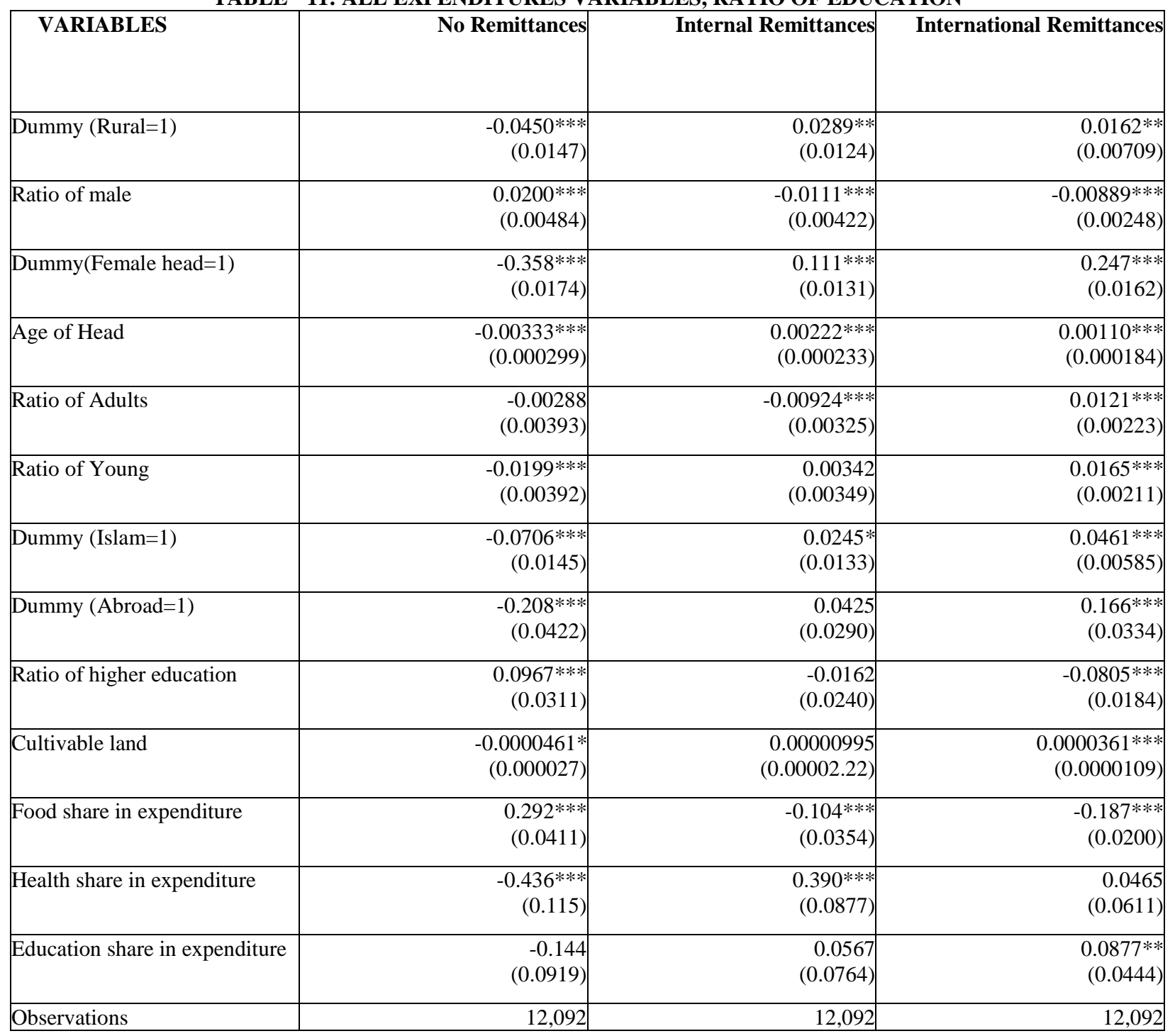

*Note: Standard errors in parentheses. *** $p<0.01$, ** $p<0.05$, * $p<0.1$. Pseudo $R^{2}=0.1159$ 
TABLE 12: ALL EXPENDITURE VARIABLES, ADULT HEADS, DUMMY OF EDUCATION

\begin{tabular}{|c|c|c|c|}
\hline VARIABLES & No Remittances & Internal Remittances & International Remittances \\
\hline Dummy (Rural=1) & $\begin{array}{r}-0.0422 * * * \\
(0.0146)\end{array}$ & $\begin{array}{r}0.0270 * * \\
(0.0124)\end{array}$ & $\begin{array}{r}0.0151 * * \\
(0.00664)\end{array}$ \\
\hline Ratio of male & $\begin{array}{r}0.0167 * * * \\
(0.00486)\end{array}$ & $\begin{array}{c}-0.00804 * \\
(0.00428)\end{array}$ & $\begin{array}{r}-0.00867 * * * \\
(0.00231)\end{array}$ \\
\hline Dummy(Female head=1) & $\begin{array}{r}-0.379 * * * \\
(0.0184)\end{array}$ & $\begin{array}{r}0.109 * * * \\
(0.0137)\end{array}$ & $\begin{array}{r}0.271^{* * * *} \\
(0.0174)\end{array}$ \\
\hline Age of Head & $\begin{array}{r}-0.00228 * * * \\
(0.000411)\end{array}$ & $\begin{array}{r}0.00197 * * * \\
(0.000320)\end{array}$ & $\begin{array}{r}0.000314 \\
(0.000228)\end{array}$ \\
\hline Ratio of Adults & $\begin{array}{r}-0.00467 \\
(0.00447)\end{array}$ & $\begin{array}{r}-0.00800^{* *} \\
(0.00386)\end{array}$ & $\begin{array}{r}0.0127^{* * * *} \\
(0.00220)\end{array}$ \\
\hline Ratio of Young & $\begin{array}{r}-0.0183 * * * \\
(0.00399)\end{array}$ & $\begin{array}{r}0.00238 \\
(0.00354)\end{array}$ & $\begin{array}{r}0.0159 * * * \\
(0.00208)\end{array}$ \\
\hline Dummy (Islam=1) & $\begin{array}{r}-0.0617^{* * * *} \\
(0.0151)\end{array}$ & $\begin{array}{r}0.0211 \\
(0.0140)\end{array}$ & $\begin{array}{r}0.0406 * * * \\
(0.00576)\end{array}$ \\
\hline Dummy (Abroad=1) & $\begin{array}{r}-0.217 * * * \\
(0.0445)\end{array}$ & $\begin{array}{r}0.0638 * * \\
(0.0315)\end{array}$ & $\begin{array}{r}0.153^{* * * *} \\
(0.0339)\end{array}$ \\
\hline Dummy ( 1 if $\geq$ SSC) & $\begin{array}{r}0.0307 * * * \\
(0.0119)\end{array}$ & $\begin{array}{r}-0.0159 \\
(0.00967)\end{array}$ & $\begin{array}{c}-0.0148 * * \\
(0.00595)\end{array}$ \\
\hline Cultivable land & $\begin{array}{r}-0.0000587 * * \\
(0.0000282)\end{array}$ & $\begin{array}{r}0.0000269 \\
(0.000023)\end{array}$ & $\begin{array}{r}0.0000318 * * * \\
(0.0000107)\end{array}$ \\
\hline Food share in expenditure & $\begin{array}{r}0.272 * * * \\
(0.0426)\end{array}$ & $\begin{array}{r}-0.0948 * * \\
(0.0369)\end{array}$ & $\begin{array}{r}-0.178^{* * * *} \\
(0.0194)\end{array}$ \\
\hline Health share in expenditure & $\begin{array}{r}-0.415^{* * * *} \\
(0.115)\end{array}$ & $\begin{array}{r}0.373 * * * \\
(0.0875)\end{array}$ & $\begin{array}{r}0.0413 \\
(0.0571)\end{array}$ \\
\hline Education share in expenditure & $\begin{array}{r}-0.124 \\
(0.0927)\end{array}$ & $\begin{array}{r}0.0733 \\
(0.0761)\end{array}$ & $\begin{array}{r}0.0505 \\
(0.0431)\end{array}$ \\
\hline Observations & 10,973 & 10,973 & 10,973 \\
\hline
\end{tabular}

*Note: Standard errors in parentheses. *** $p<0.01$, ** $p<0.05$, * $p<0.1$. Pseudo $R^{2}=0.1206$ 
TABLE 13: ALL EXPENDITURE VARIABLES, ADULT HEADS, RATIO OF EDUCATION

\begin{tabular}{|c|c|c|c|}
\hline VARIABLES & No Remittances & Internal Remittances & International Remittances \\
\hline Dummy (Rural=1) & $\begin{array}{r}-0.0405^{* * * *} \\
(0.0146)\end{array}$ & $\begin{array}{r}0.0270 * * \\
(0.0123)\end{array}$ & $\begin{array}{r}0.0135 * * \\
(0.00660)\end{array}$ \\
\hline Ratio of male & $\begin{array}{r}0.0169 * * * \\
(0.00487)\end{array}$ & $\begin{array}{c}-0.00807 * \\
(0.00429)\end{array}$ & $\begin{array}{r}-0.00879 * * * \\
(0.00230)\end{array}$ \\
\hline Dummy(Female head=1) & $\begin{array}{r}-0.377 * * * \\
(0.0185)\end{array}$ & $\begin{array}{r}0.109 * * * \\
(0.0138)\end{array}$ & $\begin{array}{r}0.267 * * * \\
(0.0174)\end{array}$ \\
\hline Age of Head & $\begin{array}{r}-0.00231^{* * *} \\
(0.000412)\end{array}$ & $\begin{array}{r}0.00198 * * * \\
(0.000321)\end{array}$ & $\begin{array}{r}0.000338 \\
(0.000228)\end{array}$ \\
\hline Ratio of Adults & $\begin{array}{r}-0.00380 \\
(0.00445)\end{array}$ & $\begin{array}{r}-0.00859 * * \\
(0.00385)\end{array}$ & $\begin{array}{r}0.0124 * * * \\
(0.00217)\end{array}$ \\
\hline Ratio of Young & $\begin{array}{r}-0.0173^{* * * *} \\
(0.00401)\end{array}$ & $\begin{array}{r}0.00219 \\
(0.00356)\end{array}$ & $\begin{array}{r}0.0152 * * * \\
(0.00207)\end{array}$ \\
\hline Dummy (Islam=1) & $\begin{array}{r}-0.0607 * * * \\
(0.0152)\end{array}$ & $\begin{array}{r}0.0210 \\
(0.0141)\end{array}$ & $\begin{array}{r}0.0397 * * * \\
(0.00577)\end{array}$ \\
\hline Dummy (Abroad=1) & $\begin{array}{r}-0.216^{* * *} \\
(0.0447)\end{array}$ & $\begin{array}{r}0.0644 * * \\
(0.0316)\end{array}$ & $\begin{array}{r}0.152^{* * * *} \\
(0.0340)\end{array}$ \\
\hline Ratio of higher education & $\begin{array}{r}0.0994 * * * \\
(0.0314)\end{array}$ & $\begin{array}{r}-0.0314 \\
(0.0254)\end{array}$ & $\begin{array}{r}-0.0680 \text { **** } \\
(0.0174)\end{array}$ \\
\hline Cultivable land & $\begin{array}{r}-0.0000607^{* *} \\
(0.0000282)\end{array}$ & $\begin{array}{r}0.000026 \\
(0.000023)\end{array}$ & $\begin{array}{r}0.0000348^{* * * *} \\
(0.0000107)\end{array}$ \\
\hline Food share in expenditure & $\begin{array}{r}0.279 * * * \\
(0.0427)\end{array}$ & $\begin{array}{r}-0.0954 * * * \\
(0.0370)\end{array}$ & $\begin{array}{r}-0.184 * * * \\
(0.0193)\end{array}$ \\
\hline Health share in expenditure & $\begin{array}{r}-0.407^{* * *} \\
(0.115)\end{array}$ & $\begin{array}{r}0.373^{* * *} \\
(0.0872)\end{array}$ & $\begin{array}{r}0.0346 \\
(0.0576)\end{array}$ \\
\hline Education share in expenditure & $\begin{array}{r}-0.130 \\
(0.0917)\end{array}$ & $\begin{array}{r}0.0624 \\
(0.0765)\end{array}$ & $\begin{array}{r}0.0675 \\
(0.0428)\end{array}$ \\
\hline Observations & 10,973 & 10,973 & 10,973 \\
\hline
\end{tabular}

*Note: Standard errors in parentheses. *** $p<0.01$, ** $p<0.05$, * $p<0.1$. Pseudo $R^{2}=0.1215$ 
TABLE 14: ALL EXPENDITURE VARIABLES, EXPENDITURE LESS THAN TK 2,00,000

\begin{tabular}{|c|c|c|c|}
\hline VARIABLES & No Remittances & Internal Remittances & International Remittances \\
\hline Dummy (Rural=1) & $\begin{array}{r}-0.0496 * * * \\
(0.0134)\end{array}$ & $\begin{array}{r}0.0292 * * \\
(0.0120)\end{array}$ & $\begin{array}{r}0.0204 * * * \\
(0.00511)\end{array}$ \\
\hline Ratio of male & $\begin{array}{r}0.0231 * * * \\
(0.00660)\end{array}$ & $\begin{array}{r}-0.0179 * * * \\
(0.00582)\end{array}$ & $\begin{array}{r}-0.00525^{* *} \\
(0.00250)\end{array}$ \\
\hline Dummy(Female head=1) & $\begin{array}{r}-0.257 * * * \\
(0.0190)\end{array}$ & $\begin{array}{r}0.120 * * * \\
(0.0161)\end{array}$ & $\begin{array}{r}0.138 * * * \\
(0.0154)\end{array}$ \\
\hline Age of Head & $\begin{array}{r}-0.00186 * * * \\
(0.000325)\end{array}$ & $\begin{array}{r}0.00175^{* * *} \\
(0.000288)\end{array}$ & $\begin{array}{r}0.000114 \\
(0.000160)\end{array}$ \\
\hline Ratio of Adults & $\begin{array}{c}0.0151 * * \\
(0.00647)\end{array}$ & $\begin{array}{r}-0.0138 * * \\
(0.00583)\end{array}$ & $\begin{array}{r}-0.00131 \\
(0.00227)\end{array}$ \\
\hline Ratio of Young & $\begin{array}{r}-0.00819 \\
(0.00539)\end{array}$ & $\begin{array}{r}0.00210 \\
(0.00488)\end{array}$ & $\begin{array}{r}0.00609 * * * \\
(0.00215)\end{array}$ \\
\hline Dummy (Islam=1) & $\begin{array}{r}-0.0489 * * * \\
(0.0143)\end{array}$ & $\begin{array}{r}0.0274 * * \\
(0.0134)\end{array}$ & $\begin{array}{r}0.0215 * * * \\
(0.00435)\end{array}$ \\
\hline Dummy (Abroad=1) & $\begin{array}{r}-0.428 * * * \\
(0.103)\end{array}$ & $\begin{array}{c}0.210 * * \\
(0.0999)\end{array}$ & $\begin{array}{c}0.218 * * \\
(0.0972)\end{array}$ \\
\hline Dummy ( 1 if $\geq$ SSC) & $\begin{array}{r}0.0202 \\
(0.0176)\end{array}$ & $\begin{array}{r}-0.00710 \\
(0.0164)\end{array}$ & $\begin{array}{r}-0.0131^{* * *} \\
(0.00590)\end{array}$ \\
\hline Cultivable land & $\begin{array}{r}-.0 .0000730 \\
(0.00006)\end{array}$ & $\begin{array}{r}0.0000322 \\
(0.0000541)\end{array}$ & $\begin{array}{r}0.0000409 * * \\
(0.0000199)\end{array}$ \\
\hline Food share in expenditure & $\begin{array}{r}0.199 * * * \\
(0.0581)\end{array}$ & $\begin{array}{c}-0.0806 \\
(0.0520)\end{array}$ & $\begin{array}{r}-0.118 * * * \\
(0.0218)\end{array}$ \\
\hline Health share in expenditure & $\begin{array}{r}-0.372 * * \\
(0.177)\end{array}$ & $\begin{array}{r}0.489 * * * \\
(0.144)\end{array}$ & $\begin{array}{r}-0.117 \\
(0.0789)\end{array}$ \\
\hline Education share in expenditure & $\begin{array}{r}-0.445^{* * *} \\
(0.158)\end{array}$ & $\begin{array}{r}0.267 * * \\
(0.133)\end{array}$ & $\begin{array}{r}0.178^{* * *} \\
(0.0547)\end{array}$ \\
\hline Observations & 6,672 & 6,672 & 6,672 \\
\hline
\end{tabular}

*Note: Standard errors in parentheses. *** $p<0.01$, ** $p<0.05$, * $p<0.1$. Pseudo $R^{2}=0.1263$ 
TABLE 15: ALL EXPENDITURE VARIABLES, EXPENDITURE FROM TK 2,00,000 TO TK 5,00,000

\begin{tabular}{|c|c|c|c|}
\hline VARIABLES & No Remittances & Internal Remittances & International Remittances \\
\hline Dummy (Rural=1) & $\begin{array}{r}-0.0731^{* * *} \\
(0.0211)\end{array}$ & $\begin{array}{r}0.0359 * * \\
(0.0164)\end{array}$ & $\begin{array}{r}0.0371 * * * \\
(0.0123)\end{array}$ \\
\hline Ratio of male & $\begin{array}{r}0.0229 * * * \\
(0.00785)\end{array}$ & $\begin{array}{r}-0.00817 \\
(0.00626)\end{array}$ & $\begin{array}{r}-0.0148^{* * * *} \\
(0.00488)\end{array}$ \\
\hline Dummy(Female head=1) & $\begin{array}{r}-0.493 * * * \\
(0.0270)\end{array}$ & $\begin{array}{r}0.105^{* * * *} \\
(0.0229)\end{array}$ & $\begin{array}{r}0.388 * * * \\
(0.0272)\end{array}$ \\
\hline Age of Head & $\begin{array}{r}-0.00502^{* * *} \\
(0.000621)\end{array}$ & $\begin{array}{r}0.00269 * * * \\
(0.000438)\end{array}$ & $\begin{array}{r}0.00234 * * * \\
(0.000444)\end{array}$ \\
\hline Ratio of Adults & $\begin{array}{r}0.0133 * * \\
(0.00638)\end{array}$ & $\begin{array}{r}-0.0174 * * * \\
(0.00475)\end{array}$ & $\begin{array}{r}0.00406 \\
(0.00441)\end{array}$ \\
\hline Ratio of Young & $\begin{array}{c}-0.0138 * * \\
(0.00657)\end{array}$ & $\begin{array}{r}-0.000489 \\
(0.00522)\end{array}$ & $\begin{array}{r}0.0143 * * * \\
(0.00467)\end{array}$ \\
\hline Dummy (Islam=1) & $\begin{array}{r}-0.0931^{* * *} \\
(0.0238)\end{array}$ & $\begin{array}{r}0.0210 \\
(0.0206)\end{array}$ & $\begin{array}{r}0.0721^{* * * *} \\
(0.0110)\end{array}$ \\
\hline Dummy (Abroad=1) & $\begin{array}{r}-0.154 * * * \\
(0.0495)\end{array}$ & $\begin{array}{c}0.00103 \\
(0.0302)\end{array}$ & $\begin{array}{r}0.153^{* * *} \\
(0.0405)\end{array}$ \\
\hline Dummy (1 if $\geq$ SSC) & $\begin{array}{r}0.0482 * * * \\
(0.0165)\end{array}$ & $\begin{array}{r}-0.0128 \\
(0.0124)\end{array}$ & $\begin{array}{r}-0.0354^{* * * *} \\
(0.0102)\end{array}$ \\
\hline Cultivable land & $\begin{array}{r}-0.0000342 \\
(0.0000428)\end{array}$ & $\begin{array}{r}0.0000138 \\
(0.0000322)\end{array}$ & $\begin{array}{r}0.0000204 \\
(0.0000266)\end{array}$ \\
\hline Food share in expenditure & $\begin{array}{r}0.238 * * * \\
(0.0668)\end{array}$ & $\begin{array}{r}-0.0699 \\
(0.0518)\end{array}$ & $\begin{array}{r}-0.168 * * * \\
(0.0410)\end{array}$ \\
\hline Health share in expenditure & $\begin{array}{r}-0.614 * * * \\
(0.186)\end{array}$ & $\begin{array}{r}0.447 * * * \\
(0.125)\end{array}$ & $\begin{array}{r}0.168 \\
(0.124)\end{array}$ \\
\hline Education share in expenditure & $\begin{array}{r}-0.0945 \\
(0.149)\end{array}$ & $\begin{array}{r}0.0684 \\
(0.113)\end{array}$ & $\begin{array}{r}0.0261 \\
(0.0996)\end{array}$ \\
\hline Observations & 4,800 & 4,800 & 4,800 \\
\hline
\end{tabular}

*Note: Standard errors in parentheses. *** $p<0.01$, ** $p<0.05$, * $p<0.1$. Pseudo $R^{2}=0.1252$ 
TABLE 16: ALL EXPENDITURE VARIABLES, EXPENDITURE ABOVE TK 5,00,000

\begin{tabular}{|c|c|c|c|}
\hline VARIABLES & No Remittances & Internal Remittances & International Remittances \\
\hline Dummy (Rural=1) & $\begin{array}{r}-0.0340 \\
(0.0435)\end{array}$ & $\begin{array}{r}0.0135 \\
(0.0316)\end{array}$ & $\begin{array}{r}0.0205 \\
(0.0328)\end{array}$ \\
\hline Ratio of male & $\begin{array}{r}0.0304 \\
(0.0192)\end{array}$ & $\begin{array}{r}-0.00563 \\
(0.0142)\end{array}$ & $\begin{array}{c}-0.0248 * \\
(0.0143)\end{array}$ \\
\hline Dummy(Female head=1) & $\begin{array}{r}-0.405^{* * *} \\
(0.0874)\end{array}$ & $\begin{array}{r}-0.0149 \\
(0.0489)\end{array}$ & $\begin{array}{r}0.420^{* * * *} \\
(0.0900)\end{array}$ \\
\hline Age of Head & $\begin{array}{r}-0.00682 * * * \\
(0.00166)\end{array}$ & $\begin{array}{r}0.00204 * \\
(0.00116)\end{array}$ & $\begin{array}{r}0.00478^{* * * *} \\
(0.00124)\end{array}$ \\
\hline Ratio of Adults & $\begin{array}{r}-0.00946 \\
(0.0153)\end{array}$ & $\begin{array}{r}-0.00174 \\
(0.0112)\end{array}$ & $\begin{array}{r}0.0112 \\
(0.0114)\end{array}$ \\
\hline Ratio of Young & $\begin{array}{r}-0.0241 \\
(0.0155)\end{array}$ & $\begin{array}{r}-0.00302 \\
(0.0116)\end{array}$ & $\begin{array}{r}0.0272^{* *} \\
(0.0112)\end{array}$ \\
\hline Dummy (Islam=1) & $\begin{array}{r}-0.161^{* * *} \\
(0.0447)\end{array}$ & $\begin{array}{r}0.0268 \\
(0.0380)\end{array}$ & $\begin{array}{r}0.134 * * * \\
(0.0255)\end{array}$ \\
\hline Dummy (Abroad=1) & $\begin{array}{r}-0.163 \\
(0.126)\end{array}$ & $\begin{array}{r}-0.0635 \\
(0.0525)\end{array}$ & $\begin{array}{c}0.227 * \\
(0.120)\end{array}$ \\
\hline Dummy (1 if $\geq$ SSC) & $\begin{array}{r}0.113^{* * *} \\
(0.0431)\end{array}$ & $\begin{array}{r}-0.0237 \\
(0.0306)\end{array}$ & $\begin{array}{r}-0.0895 * * * \\
(0.0347)\end{array}$ \\
\hline Cultivable land & $\begin{array}{r}0.0000535 \\
(0.0000566)\end{array}$ & $\begin{array}{r}-0.0000471 \\
(0.0000465)\end{array}$ & $\begin{array}{r}-0.00000646 \\
(0.0000394)\end{array}$ \\
\hline Food share in expenditure & $\begin{array}{r}-0.0269 \\
(0.109)\end{array}$ & $\begin{array}{r}-0.0527 \\
(0.0760)\end{array}$ & $\begin{array}{r}0.0797 \\
(0.0817)\end{array}$ \\
\hline Health share in expenditure & $\begin{array}{r}-0.162 \\
(0.281)\end{array}$ & $\begin{array}{r}0.0423 \\
(0.190)\end{array}$ & $\begin{array}{r}0.120 \\
(0.210)\end{array}$ \\
\hline Education share in expenditure & $\begin{array}{r}1.312^{* * * *} \\
(0.400)\end{array}$ & $\begin{array}{r}-0.396 \\
(0.271)\end{array}$ & $\begin{array}{r}-0.916^{* * * *} \\
(0.341)\end{array}$ \\
\hline Observations & 620 & 620 & 620 \\
\hline
\end{tabular}

*Note: Standard errors in parentheses. *** $p<0.01$, ** $p<0.05$, * $p<0.1$. Pseudo $R^{2}=0.1328$ 
TABLE 17: ONLY FOOD EXPENDITURE, DUMMY OF HIGHER EDUCATION

\begin{tabular}{|c|c|c|c|}
\hline VARIABLES & No Remittances & Internal Remittances & International Remittances \\
\hline Dummy (Rural=1) & $\begin{array}{r}-0.0497 * * * \\
(0.0147)\end{array}$ & $\begin{array}{r}0.0313^{* *} \\
(0.0124)\end{array}$ & $\begin{array}{r}0.0184 * * * \\
(0.00712)\end{array}$ \\
\hline Ratio of male & $\begin{array}{r}0.0196 * * * \\
(0.00483)\end{array}$ & $\begin{array}{r}-0.0109 * * * \\
(0.00422)\end{array}$ & $\begin{array}{r}-0.00869 * * * \\
(0.00249)\end{array}$ \\
\hline Dummy(Female head=1) & $\begin{array}{r}-0.361 * * * \\
(0.0172)\end{array}$ & $\begin{array}{r}0.109 * * * \\
(0.0131)\end{array}$ & $\begin{array}{r}0.251 * * * \\
(0.0161)\end{array}$ \\
\hline Age of head & $\begin{array}{r}-0.00339 * * * \\
(0.000299)\end{array}$ & $\begin{array}{r}0.00229 * * * \\
(0.000232)\end{array}$ & $\begin{array}{r}0.00110^{* * *} \\
(0.000186)\end{array}$ \\
\hline Ratio of adults & $\begin{array}{r}-0.00297 \\
(0.00394)\end{array}$ & $\begin{array}{r}-0.00924 * * * \\
(0.00326)\end{array}$ & $\begin{array}{r}0.0122 * * * \\
(0.00224)\end{array}$ \\
\hline Ratio of young & $\begin{array}{r}-0.0214^{* * * *} \\
(0.00391)\end{array}$ & $\begin{array}{r}0.00384 \\
(0.00348)\end{array}$ & $\begin{array}{r}0.0175^{* * * *} \\
(0.00212)\end{array}$ \\
\hline Religion ( Islam=1) & $\begin{array}{r}-0.0719 * * * \\
(0.0145)\end{array}$ & $\begin{array}{r}0.0247 * \\
(0.0133)\end{array}$ & $\begin{array}{r}0.0472 * * * \\
(0.00586)\end{array}$ \\
\hline Dummy (Abroad=1) & $\begin{array}{r}-0.209 * * * \\
(0.0417)\end{array}$ & $\begin{array}{r}0.0424 \\
(0.0288)\end{array}$ & $\begin{array}{r}0.166^{* * * *} \\
(0.0333)\end{array}$ \\
\hline Dummy (1 if $\geq$ SSC) & $\begin{array}{c}0.0215^{*} \\
(0.0118)\end{array}$ & $\begin{array}{r}-0.00783 \\
(0.00953)\end{array}$ & $\begin{array}{r}-0.0137 * * \\
(0.00622)\end{array}$ \\
\hline Cultivable land & $\begin{array}{r}-0.0000442 \\
(0.00003)\end{array}$ & $\begin{array}{r}0.0000118 \\
(0.00002)\end{array}$ & $\begin{array}{r}0.0000324 * * * \\
(0.00001)\end{array}$ \\
\hline Food share in expenditure & $\begin{array}{r}0.334 * * * \\
(0.0373)\end{array}$ & $\begin{array}{r}-0.146 * * * \\
(0.0314)\end{array}$ & $\begin{array}{r}-0.189 * * * \\
(0.0186)\end{array}$ \\
\hline Observations & 12,092 & 12,092 & 12,092 \\
\hline
\end{tabular}

*Note: Standard errors in parentheses. *** $p<0.01$, ** $p<0.05$, * $p<0.1$. Pseudo $R^{2}=0.1131$ 
TABLE 18: ONLY FOOD EXPENDITURE, RATIO OF HIGHER EDUCATION

\begin{tabular}{|c|c|c|c|}
\hline VARIABLES & No Remittances & Internal Remittances & International Remittances \\
\hline Dummy (Rural=1) & $\begin{array}{r}-0.0467 * * * \\
(0.0147)\end{array}$ & $\begin{array}{r}0.0307^{* *} \\
(0.0124)\end{array}$ & $\begin{array}{r}0.0160 * * \\
(0.00708)\end{array}$ \\
\hline Ratio of male & $\begin{array}{r}0.0198 * * * \\
(0.00484)\end{array}$ & $\begin{array}{r}-0.0110 * * * \\
(0.00422)\end{array}$ & $\begin{array}{r}-0.00887 * * * * \\
(0.00248)\end{array}$ \\
\hline Dummy(Female head=1) & $\begin{array}{r}-0.358 * * * \\
(0.0173)\end{array}$ & $\begin{array}{r}0.110^{* * * *} \\
(0.0131)\end{array}$ & $\begin{array}{r}0.249 * * * \\
(0.0161)\end{array}$ \\
\hline Age of head & $\begin{array}{r}-0.00339 * * * \\
(0.000298)\end{array}$ & $\begin{array}{r}0.00229 * * * \\
(0.000232)\end{array}$ & $\begin{array}{r}0.00109 * * * \\
(0.000184)\end{array}$ \\
\hline Ratio of adults & $\begin{array}{r}-0.00293 \\
(0.00392)\end{array}$ & $\begin{array}{r}-0.00939 * * * \\
(0.00326)\end{array}$ & $\begin{array}{r}0.0123 * * * \\
(0.00220)\end{array}$ \\
\hline Ratio of young & $\begin{array}{r}-0.0204 * * * \\
(0.00392)\end{array}$ & $\begin{array}{r}0.00365 \\
(0.00349)\end{array}$ & $\begin{array}{r}0.0168 * * * \\
(0.00210)\end{array}$ \\
\hline Religion ( Islam=1) & $\begin{array}{r}-0.0708 * * * \\
(0.0145)\end{array}$ & $\begin{array}{c}0.0245 * \\
(0.0133)\end{array}$ & $\begin{array}{r}0.0463 * * * \\
(0.00585)\end{array}$ \\
\hline Dummy (Abroad=1) & $\begin{array}{r}-0.208^{* * *} \\
(0.0419)\end{array}$ & $\begin{array}{r}0.0431 \\
(0.0289)\end{array}$ & $\begin{array}{r}0.165^{* * *} \\
(0.0332)\end{array}$ \\
\hline Ratio of higher education & $\begin{array}{r}0.0980 * * * \\
(0.0309)\end{array}$ & $\begin{array}{r}-0.0240 \\
(0.0237)\end{array}$ & $\begin{array}{r}-0.0741^{* * * *} \\
(0.0182)\end{array}$ \\
\hline Cultivable land & $\begin{array}{r}-0.000049 * \\
(0.0000268)\end{array}$ & $\begin{array}{r}0.0000125 \\
(0.0000226)\end{array}$ & $\begin{array}{r}0.0000365^{* * * *} \\
(0.0000108)\end{array}$ \\
\hline Food share in expenditure & $\begin{array}{r}0.349 * * * \\
(0.0373)\end{array}$ & $\begin{array}{r}-0.150^{* * *} \\
(0.0314)\end{array}$ & $\begin{array}{r}-0.199 * * * \\
(0.0184)\end{array}$ \\
\hline Observations & 12,092 & 12,092 & 12,092 \\
\hline
\end{tabular}

*Note: Standard errors in parentheses. *** $p<0.01$, ** $p<0.05$, * $p<0.1$. Pseudo $R^{2}=0.1143$ 
TABLE 19: ADULT HEAD, ONLY FOOD EXPENDITURE, DUMMY OF HIGHER EDUCATION

\begin{tabular}{|c|c|c|c|}
\hline VARIABLES & No Remittances & Internal Remittances & International Remittances \\
\hline Dummy (Rural=1) & $\begin{array}{r}-0.0441^{* * * *} \\
(0.0146)\end{array}$ & $\begin{array}{r}0.0291 * * \\
(0.0124)\end{array}$ & $\begin{array}{r}0.0150 * * \\
(0.00661)\end{array}$ \\
\hline Ratio of male & $\begin{array}{r}0.0166 * * * \\
(0.00486)\end{array}$ & $\begin{array}{r}-0.00795 * \\
(0.00429)\end{array}$ & $\begin{array}{r}-0.00866 * * * \\
(0.00231)\end{array}$ \\
\hline Dummy(Female head=1) & $\begin{array}{r}-0.379 * * * \\
(0.0183)\end{array}$ & $\begin{array}{r}0.108^{* * *} \\
(0.0138)\end{array}$ & $\begin{array}{r}0.271 * * * \\
(0.0173)\end{array}$ \\
\hline Age of head & $\begin{array}{r}-0.00234 * * * \\
(0.000410)\end{array}$ & $\begin{array}{r}0.00203^{* * *} \\
(0.000320)\end{array}$ & $\begin{array}{r}0.000317 \\
(0.000228)\end{array}$ \\
\hline Ratio of adults & $\begin{array}{r}-0.00491 \\
(0.00447)\end{array}$ & $\begin{array}{r}-0.00780^{* *} \\
(0.00386)\end{array}$ & $\begin{array}{r}0.0127 * * * \\
(0.00219)\end{array}$ \\
\hline Ratio of young & $\begin{array}{r}-0.0189 * * * \\
(0.00399)\end{array}$ & $\begin{array}{r}0.00283 \\
(0.00354)\end{array}$ & $\begin{array}{r}0.0160 * * * \\
(0.00207)\end{array}$ \\
\hline Dummy (Islam=1) & $\begin{array}{r}-0.0616 * * * \\
(0.0152)\end{array}$ & $\begin{array}{r}0.0209 \\
(0.0141)\end{array}$ & $\begin{array}{r}0.0406 * * * \\
(0.00576)\end{array}$ \\
\hline Dummy (Abroad=1) & $\begin{array}{r}-0.217^{* * *} \\
(0.0443)\end{array}$ & $\begin{array}{r}0.0645^{* *} \\
(0.0314)\end{array}$ & $\begin{array}{r}0.152 * * * \\
(0.0339)\end{array}$ \\
\hline Dummy ( 1 if $\geq$ SSC) & $\begin{array}{r}0.0315 * * * \\
(0.0118)\end{array}$ & $\begin{array}{r}-0.0178 * \\
(0.00953)\end{array}$ & $\begin{array}{r}-0.0137 * * \\
(0.00599)\end{array}$ \\
\hline Cultivable land & $\begin{array}{r}-0.0000601 * * \\
(0.0000276)\end{array}$ & $\begin{array}{r}0.0000282 \\
(0.000023)\end{array}$ & $\begin{array}{r}.0000319 * * * \\
(0.0000106)\end{array}$ \\
\hline Food share in expenditure & $\begin{array}{r}0.326 * * * \\
(0.0391)\end{array}$ & $\begin{array}{r}-0.141 * * * \\
(0.0330)\end{array}$ & $\begin{array}{r}-0.186^{* * * *} \\
(0.0181)\end{array}$ \\
\hline Observations & 10,973 & 10,973 & 10,973 \\
\hline
\end{tabular}

*Note: Standard errors in parentheses. *** $p<0.01$, ** $p<0.05$, * $p<0.1$. Pseudo $R^{2}=0.1191$ 
TABLE 20: ADULT HEAD, ONLY FOOD EXPENDITURE, RATIO OF HIGHER EDUCATION

\begin{tabular}{|c|c|c|c|}
\hline VARIABLES & No Remittances & Internal Remittances & International Remittances \\
\hline Dummy (Rural=1) & $\begin{array}{r}-0.0423 * * * \\
(0.0146)\end{array}$ & $\begin{array}{r}0.0290 * * \\
(0.0123)\end{array}$ & $\begin{array}{r}0.0133 * * \\
(0.00659)\end{array}$ \\
\hline Ratio of male & $\begin{array}{r}0.0167 * * * \\
(0.00486)\end{array}$ & $\begin{array}{c}-0.00799 * \\
(0.00429)\end{array}$ & $\begin{array}{r}-0.00875 * * * \\
(0.00230)\end{array}$ \\
\hline Dummy(Female head=1) & $\begin{array}{r}-0.377^{* * * *} \\
(0.0184)\end{array}$ & $\begin{array}{r}0.109 * * * \\
(0.0139)\end{array}$ & $\begin{array}{r}0.268 * * * \\
(0.0174)\end{array}$ \\
\hline Age of head & $\begin{array}{r}-0.00238 * * * \\
(0.000411)\end{array}$ & $\begin{array}{r}0.00204^{* * *} \\
(0.000321)\end{array}$ & $\begin{array}{r}0.000338 \\
(0.000227)\end{array}$ \\
\hline Ratio of adults & $\begin{array}{r}-0.00401 \\
(0.00444)\end{array}$ & $\begin{array}{r}-0.00849 * * \\
(0.00385)\end{array}$ & $\begin{array}{r}0.0125 * * * \\
(0.00216)\end{array}$ \\
\hline Ratio of young & $\begin{array}{r}-0.0179 * * * \\
(0.00400)\end{array}$ & $\begin{array}{r}0.00254 \\
(0.00355)\end{array}$ & $\begin{array}{r}0.0154 * * * \\
(0.00206)\end{array}$ \\
\hline Dummy (Islam=1) & $\begin{array}{r}-0.0605^{* * *} \\
(0.0152)\end{array}$ & $\begin{array}{r}0.0207 \\
(0.0141)\end{array}$ & $\begin{array}{r}0.0398 * * * \\
(0.00578)\end{array}$ \\
\hline Dummy (Abroad=1) & $\begin{array}{r}-0.216 * * * \\
(0.0446)\end{array}$ & $\begin{array}{r}0.0654 * * \\
(0.0315)\end{array}$ & $\begin{array}{r}0.151^{* * * *} \\
(0.0339)\end{array}$ \\
\hline Ratio of higher education & $\begin{array}{r}0.101^{* * * *} \\
(0.0312)\end{array}$ & $\begin{array}{r}-0.0379 \\
(0.0252)\end{array}$ & $\begin{array}{r}-0.0631^{* * * *} \\
(0.0171)\end{array}$ \\
\hline Cultivable land & $\begin{array}{r}-0.0000621 * * \\
(0.0000276)\end{array}$ & $\begin{array}{r}0.0000273 \\
(0.0000231)\end{array}$ & $\begin{array}{r}0.0000348^{* * * *} \\
(0.000014)\end{array}$ \\
\hline Food share in expenditure & $\begin{array}{r}0.334 * * * \\
(0.0390)\end{array}$ & $\begin{array}{r}-0.141 * * * \\
(0.0331)\end{array}$ & $\begin{array}{r}-0.193^{* * * *} \\
(0.0179)\end{array}$ \\
\hline Observations & 10,973 & 10,973 & 10,973 \\
\hline
\end{tabular}

*Note: Standard errors in parentheses. *** $p<0.01$, ** $p<0.05$, * $p<0.1$. Pseudo $R^{2}=0.1199$ 
TABLE 21: ONLY FOOD EXPENDITURE, EXPENDITURE LESS THAN TK 2,00,000

\begin{tabular}{|c|c|c|c|}
\hline VARIABLES & No Remittances & Internal Remittances & International Remittances \\
\hline Dummy (Rural=1) & $\begin{array}{r}-0.0521 * * * \\
(0.0134)\end{array}$ & $\begin{array}{r}0.0321 * * * \\
(0.0120)\end{array}$ & $\begin{array}{r}0.0200 * * * \\
(0.00517)\end{array}$ \\
\hline Ratio of male & $\begin{array}{r}0.0221 * * * \\
(0.00663)\end{array}$ & $\begin{array}{r}-0.0169 * * * \\
(0.00585)\end{array}$ & $\begin{array}{r}-0.00514^{* * *} \\
(0.00256)\end{array}$ \\
\hline Dummy(Female head=1) & $\begin{array}{r}-0.263^{* * * *} \\
(0.0189)\end{array}$ & $\begin{array}{r}0.119 * * * \\
(0.0161)\end{array}$ & $\begin{array}{r}0.144^{* * * *} \\
(0.0155)\end{array}$ \\
\hline Age of Head & $\begin{array}{r}-0.00195 * * * \\
(0.000319)\end{array}$ & $\begin{array}{r}0.00186 * * * \\
(0.000285)\end{array}$ & $\begin{array}{r}0.0000907 \\
(0.000159)\end{array}$ \\
\hline Ratio of Adults & $\begin{array}{r}0.0140 * * \\
(0.00644)\end{array}$ & $\begin{array}{r}-0.0135 * * \\
(0.00580)\end{array}$ & $\begin{array}{c}-0.000484 \\
(0.00225)\end{array}$ \\
\hline Ratio of Young & $\begin{array}{r}-0.0102 * \\
(0.00523)\end{array}$ & $\begin{array}{r}0.00334 \\
(0.00471)\end{array}$ & $\begin{array}{r}0.00686^{* * * *} \\
(0.00215)\end{array}$ \\
\hline Dummy (Islam=1) & $\begin{array}{r}-0.0491 * * * \\
(0.0143)\end{array}$ & $\begin{array}{r}0.0276^{* *} \\
(0.0133)\end{array}$ & $\begin{array}{r}0.0216 * * * \\
(0.00446)\end{array}$ \\
\hline Dummy (Abroad=1) & $\begin{array}{r}-0.424 * * * \\
(0.101)\end{array}$ & $\begin{array}{c}0.221^{* *} \\
(0.0930)\end{array}$ & $\begin{array}{c}0.203 * * \\
(0.0861)\end{array}$ \\
\hline Dummy (1 if $\geq$ SSC) & $\begin{array}{r}0.0146 \\
(0.0178)\end{array}$ & $\begin{array}{r}-0.00661 \\
(0.0163)\end{array}$ & $\begin{array}{r}-0.00802 \\
(0.00654)\end{array}$ \\
\hline Cultivable land & $\begin{array}{r}-0.0000746 \\
(0.0000589)\end{array}$ & $\begin{array}{r}0.00003350 \\
(0.0000526)\end{array}$ & $\begin{array}{r}0.0000411^{* * *} \\
(0.0000191)\end{array}$ \\
\hline Food share in expenditure & $\begin{array}{r}0.294 * * * \\
(0.0505)\end{array}$ & $\begin{array}{r}-0.165 * * * \\
(0.0449)\end{array}$ & $\begin{array}{r}-0.129 * * * \\
(0.0189)\end{array}$ \\
\hline Observations & 6,672 & 6,672 & 6,672 \\
\hline
\end{tabular}

*Note: Standard errors in parentheses. *** $p<0.01$, ** $p<0.05$, * $p<0.1$. Pseudo $R^{2}=0.1221$ 
TABLE 22: ONLY FOOD EXPENDITURE, EXPENDITURE BETWEEN TK 2,00,000 TO TK 5,00,000

\begin{tabular}{|c|c|c|c|}
\hline VARIABLES & No Remittances & Internal Remittances & International Remittances \\
\hline Dummy (Rural=1) & $\begin{array}{r}-0.0766^{* * *} \\
(0.0210)\end{array}$ & $\begin{array}{r}0.0386 * * \\
(0.0164)\end{array}$ & $\begin{array}{r}0.0380^{* * * *} \\
(0.0122)\end{array}$ \\
\hline Ratio of male & $\begin{array}{r}0.0232 * * * \\
(0.00784)\end{array}$ & $\begin{array}{r}-0.00840 \\
(0.00626)\end{array}$ & $\begin{array}{r}-0.0148 * * * \\
(0.00488)\end{array}$ \\
\hline Dummy(Female head=1) & $\begin{array}{r}-0.491 * * * \\
(0.0271)\end{array}$ & $\begin{array}{r}0.104^{* * * *} \\
(0.0229)\end{array}$ & $\begin{array}{r}0.388^{* * * *} \\
(0.0271)\end{array}$ \\
\hline Age of Head & $\begin{array}{r}-0.00512 * * * \\
(0.000619)\end{array}$ & $\begin{array}{r}0.00276 * * * \\
(0.000435)\end{array}$ & $\begin{array}{r}0.00235^{* * * *} \\
(0.000446)\end{array}$ \\
\hline Ratio of Adults & $\begin{array}{c}0.0135 * * \\
(0.00637)\end{array}$ & $\begin{array}{r}-0.0175^{* * *} \\
(0.00478)\end{array}$ & $\begin{array}{r}0.00406 \\
(0.00438)\end{array}$ \\
\hline Ratio of Young & $\begin{array}{c}-0.0145^{* *} \\
(0.00659)\end{array}$ & $\begin{array}{l}-1.13 e-05 \\
(0.00524)\end{array}$ & $\begin{array}{c}0.0145^{* * * *} \\
(0.00465)\end{array}$ \\
\hline Dummy (Islam=1) & $\begin{array}{r}-0.0931^{* * *} \\
(0.0240)\end{array}$ & $\begin{array}{r}0.0211 \\
(0.0208)\end{array}$ & $\begin{array}{r}0.0721^{* * * *} \\
(0.0110)\end{array}$ \\
\hline Dummy (Abroad=1) & $\begin{array}{r}-0.156 * * * \\
(0.0495)\end{array}$ & $\begin{array}{c}0.00161 \\
(0.0305)\end{array}$ & $\begin{array}{r}.155^{* * * *} \\
(0.0407)\end{array}$ \\
\hline Dummy (1 if $\geq$ SSC) & $\begin{array}{r}0.0500^{* * * *} \\
(0.0164)\end{array}$ & $\begin{array}{r}-0.0143 \\
(0.0121)\end{array}$ & $\begin{array}{r}-0.0357 * * * \\
(0.0103)\end{array}$ \\
\hline Cultivable land & $\begin{array}{r}-0.0000325 \\
(0.0000425)\end{array}$ & $\begin{array}{r}0.0000126 \\
(0.0000319)\end{array}$ & $\begin{array}{r}0.0000199 \\
(0.0000265)\end{array}$ \\
\hline Food share in expenditure & $\begin{array}{r}0.303^{* * * *} \\
(0.0607)\end{array}$ & $\begin{array}{c}-0.118^{* * *} \\
(0.0463)\end{array}$ & $\begin{array}{r}-0.184^{* * * *} \\
(0.0371)\end{array}$ \\
\hline Observations & 4,800 & 4,800 & 4,800 \\
\hline
\end{tabular}

*Note: Standard errors in parentheses. ${ }^{* * *} p<0.01$, ** $p<0.05$, * $p<0.1$. Pseudo $R^{2}=0.1232$ 
TABLE 23: ONLY FOOD EXPENDITURE, EXPENDITURE ABOVE TK 5,00,000

\begin{tabular}{|c|c|c|c|}
\hline VARIABLES & No Remittances & Internal Remittances & International Remittances \\
\hline Dummy (Rural=1) & $\begin{array}{r}-0.0565 \\
(0.0443)\end{array}$ & $\begin{array}{r}0.0210 \\
(0.0321)\end{array}$ & $\begin{array}{r}0.0355 \\
(0.0346)\end{array}$ \\
\hline Ratio of male & $\begin{array}{r}0.0272 \\
(0.0194)\end{array}$ & $\begin{array}{r}-0.00366 \\
(0.0142)\end{array}$ & $\begin{array}{c}-0.0236 \\
(0.0148)\end{array}$ \\
\hline Dummy(Female head=1) & $\begin{array}{r}-0.397 * * * \\
(0.0834)\end{array}$ & $\begin{array}{r}-0.0218 \\
(0.0464)\end{array}$ & $\begin{array}{r}0.419^{* * * *} \\
(0.0868)\end{array}$ \\
\hline Age of Head & $\begin{array}{r}-0.00752 * * * \\
(0.00169)\end{array}$ & $\begin{array}{r}0.00212 * \\
(0.00118)\end{array}$ & $\begin{array}{r}0.00540^{* * *} \\
(0.00128)\end{array}$ \\
\hline Ratio of Adults & $\begin{array}{r}-0.00264 \\
(0.0155)\end{array}$ & $\begin{array}{r}-0.00453 \\
(0.0113)\end{array}$ & $\begin{array}{c}0.00717 \\
(0.0119)\end{array}$ \\
\hline Ratio of Young & $\begin{array}{r}-0.0228 \\
(0.0157)\end{array}$ & $\begin{array}{r}-0.00340 \\
(0.0116)\end{array}$ & $\begin{array}{r}0.0262 * * \\
(0.0116)\end{array}$ \\
\hline Dummy (Islam=1) & $\begin{array}{r}-0.156^{* * *} \\
(0.0473)\end{array}$ & $\begin{array}{r}0.0198 \\
(0.0402)\end{array}$ & $\begin{array}{r}0.137 * * * \\
(0.0274)\end{array}$ \\
\hline Dummy (Abroad=1) & $\begin{array}{r}-0.176 \\
(0.125)\end{array}$ & $\begin{array}{r}-0.0640 \\
(0.0528)\end{array}$ & $\begin{array}{r}0.240 * * \\
(0.120)\end{array}$ \\
\hline Dummy ( 1 if $\geq$ SSC) & $\begin{array}{r}0.154^{* * * *} \\
(0.0429)\end{array}$ & $\begin{array}{r}-0.0339 \\
(0.0305)\end{array}$ & $\begin{array}{r}-0.120^{* * * *} \\
(0.0357)\end{array}$ \\
\hline Cultivable land & $\begin{array}{r}0.000052 \\
(0.0000576)\end{array}$ & $\begin{array}{r}-0.0000485 \\
(0.0000474)\end{array}$ & $\begin{array}{r}-0.00000348 \\
(0.0000411)\end{array}$ \\
\hline Food share in expenditure & $\begin{array}{r}-0.0858 \\
(0.108)\end{array}$ & $\begin{array}{r}-0.0349 \\
(0.0755)\end{array}$ & $\begin{array}{r}0.121 \\
(0.0833)\end{array}$ \\
\hline Observations & 620 & 620 & 620 \\
\hline
\end{tabular}

*Note: Standard errors in parentheses. *** $p<0.01$, ** $p<0.05$, * $p<0.1$. Pseudo $R^{2}=0.1328$

\section{ENDNOTES}

* The author would like to thank the Statistics and Informatics Division, Bangladesh Bureau of Statistics for making the data available. The author is also thankful to Professor Oliver Morrissey for his suggestions. All the remaining errors are the author's. 


\section{REFERENCES}

Acosta, P, Fajnzylber, P, and Lopez, H 2007, 'The impact of remittances on poverty and human capital : evidence from Latin American household surveys’, Policy Research Working Paper 4247, The World Bank.

Adams, R 2011, 'Evaluating the economic impact of international remittances on developing countries using household surveys: A literature review’, Journal of Development Studies, Vol. 47, Issue 6, pp. 809-828.

Adams, R and Cuecuecha, A 2010, 'Remittances, household expenditure and investment in Guatemala', World Development, Vol. 38, Issue 11, pp. 1626-1641.

Adams, R and Cuecuecha, A 2013, 'The impact of remittances on investment and poverty in Ghana', World Development, Vol. 50, pp. 24-40.

Cameron, C and Trivedi, P 2005, Microeconometrics: Methods and Applications. Cambridge University Press, New York.

Chowdhury, M and Rabbi, F 2014, Workers' remittances and Dutch disease in Bangladesh. The Journal of International Trade and Economic Development, Vol 23, Issue 4, pp. 455-475.

Hatemi-J, A and Salah Uddin G 2014, On the causal nexus of remittances and poverty reduction in Bangladesh. Applied Economics, Vol. 46, Issue 4, pp. 374-382.

Mahmud, W and Osmani SR 1980, Impact of emigrant workers' remittances on the Bangladesh economy. The Bangladesh Development Studies, Vol. 8, No. 3, pp. 1-28.

Mansuri, G 2006, Migration, school attainment, and child labor: evidence from rural Pakistan. Policy Research Working Paper 3945, The World Bank.

Siddique, A, Selvanathan, S and Selvanathan S, 2012, Remittances and economic growth: Empirical evidence from Bangladesh, India and Sri Lanka. Journal of Development Studies, Vol. 48, Issue 8, pp. 1045-1062.

Sikder, M and Ballis, P 2013, Remittances and life chances: a study of migrant households in rural Bangladesh. Migration and Development, Vol. 2, Issue 2, pp. 261-285.

Stahl, C and Habib, A 1989, The impact of overseas workers' remittances on indigenous industries: Evidence from Bangladesh. The Developing Economies, Vol. 27, Issue 3, pp. 269-285. 